\title{
Effect of food restriction on reproduction and lactation in house mice mated post partum
}

\author{
S. Krackow \\ Universität Konstanz, Fakultät für Biologie, Postfach 5560, 7750 Konstanz, \\ Federal Republic of Germany
}

\begin{abstract}
Summary. Primiparous, post-partum mated BALB/c bom inbred mice were allowed to raise litters of 6 young until Day 22 of lactation: 11 of 25 females were restricted to $60 \%$ of food consumption of ad-libitum fed dams after stud male removal at Day 2 of lactation. Since weight gain of restricted females during lactation was not inhibited and infanticidal behaviour was not enhanced, food deprivation can be considered to have been relatively mild. However, none of the food-restricted dams gave birth to a second litter whereas 12 of the 14 ad-libitum fed mice littered. This pregnancy failure is suggested to be due to implantation failure or abortion shortly after implantation, which is attributed to maternal manipulation rather than to immediate consequences of energetic demands of lactated young. The dynamics of the weight changes of dams and young suggest that milk production in suckling house mice drops most markedly between Days 17 and 18 of lactation, irrespective of whether the dams are non-pregnant, pregnant, or food-restricted.
\end{abstract}

Keywords: food restriction; post-partum reproduction; pregnancy failure; pup growth; house mouse

\section{Introduction}

House mice (Mus musculus) reproduce even under very disadvantageous conditions (Bronson, 1984). Food shortage apparently does not disrupt reproduction within house mouse populations (Strecker, 1954); however, if egress of mice is prevented and food supply is limited under seminatural conditions, reproduction ceases due to female infertility (Strecker \& Emlen, 1953).

In the laboratory, food restriction may affect any reproductive parameter in female house mice, e.g. age at maturity (Hamilton \& Bronson, 1985), mating rates (McClure, 1966; Marsteller \& Lynch, 1987a), ovulation rates and cycle length (Bronson \& Marsteller, 1985), implantation success and embryo resorption (Zamiri, 1978), viable litter size and birth weights of young (Smart \& Silence, 1977), mortality and growth of young (König, 1985; Marsteller \& Lynch, 1987b; Perrigo, 1987). It appears, that these reproductive manipulations of house mouse mothers are finely tuned to the level of nutritional deprivation, allowing a mother to wean a maximal number of healthy pups (König, 1985; Marsteller \& Lynch, 1987a, b; Perrigo, 1987).

However, in most food-restriction experiments the dams used were either non-pregnant or nonlactating. Since post-partum fertility can be considered a common feature within house mouse and other rodent populations (Conaway, 1971; Gilbert, 1984; Bronson, 1985), this study investigated the effect of food restriction on reproductive parameters during concurrent pregnancy and lactation in house mice.

\section{Materials and Methods}

Animal maintenance and breeding. Mature, sexually inexperienced female and experienced, fertile male BALB/c bom inbred mice were obtained from a breeding stock maintained at the University of Konstanz. Twenty-eight 
females (all 98 days of age) were then mated synchronously with males at random; the males stayed with the females during pregnancy. The breeding pairs were housed in transparent cages $(26.5 \times 42 \times 15 \mathrm{~cm})$ with feeder-tops. Standard laboratory food and water were provided ad libitum. The colony room was kept at $21^{\circ} \mathrm{C}$ and with a $12 \mathrm{~h}$ light: $12 \mathrm{~h}$ dark cycle (lights on at 07:00 h).

The cages were checked twice daily for new litters (at the beginning and the end of the light phase). The day of discovery was considered to be the day of birth and designated as Day I of lactation. The stud males were removed on Day 2 of lactation to allow for post-partum mating. The young were removed from the dams on Day 22 .

On the day of birth viable young were counted, sexed, and weighed and litters were adjusted to 6 , trying to balance the sex ratio. If too many young were born to be assigned to an experimental litter, randomly chosen ones were discarded and killed by $\mathrm{CO}_{2}$.

Treatment groups. At mating, each of the 28 pairs was assigned randomly to one of two treatments to obtain two groups of 14 pairs. In the ad-libitum fed group (Group AL), no further manipulations were conducted after removal of the stud male. Twelve of these females raised litters of 3 male and 3 female young, one had 2 male and 4 female young and the other 4 males and 2 females.

In the food-restricted group (Group FR), after removal of the males at Day 2 of lactation, $60 \%$ of the food consumed by unrestricted BALB/c bom dams was provided daily at $11: 00 \mathrm{~h}$ just after the weighing procedure (see below). Ad-libitum daily food consumption was determined during another experiment (Krackow \& Hoeck, 1989) using 12 post-partum pregnant $\mathrm{BALB} / \mathrm{c}$ bom dams bred under the same conditions as the dams used here, i.e. the dams bred in the same breeding room, raised 6 young each, and were of similar age and weight.

Group FR consisted of only 11 families since there were not enough young available on one occasion, one female did not manage to deliver the first embryo at parturition and had to be killed, and one dam lost her litter by accident. Ten of the females raised 3 male and 3 female young, one raised 1 male and 5 female young.

Weight data. Weights were determined to the nearest $0 \cdot 1 \mathrm{~g}$. Dams and litters were weighed daily at about $11: 00 \mathrm{~h}$ between Days 3 and 22 of lactation. Litters were weighed by sex, i.e. all members of each sex were weighed as a whole. Individual weights were calculated by dividing the whole-litter weights by the number of young. Weight changes referring to Day 3 of lactation were used for comparisons of weight gains during lactation.

Implantation sites. Dams were killed by $\mathrm{CO}_{2}$ at the day of their second parturition or at Day 30 , if no weight gain was detectable, and uterine scars were counted. Scars of the first parturition could easily be distinguished from those of the second. They appeared as flat, yellow spots at the mesometrial side of the uterus whereas the latter formed cones of tissue of a yellow or red appearance and were surrounded by rosettes of uterine tissue.

Statistical procedures. Weight-data of the two treatment groups were compared using the Mann-Whitney U-test, male and female young weights using the Wilcoxon signed-rank test. Comparisons of weight gain data in Group AL and FR were made by one-sided tests because food restriction predicts lower weight gain. Differences were considered significant at the $5 \%$ level.

\section{Results}

To investigate whether there were any a-priori differences in fertility or investment ability between the two groups of dams, female weight at mating and first parturition, delay between mating and parturition, and size and pup birth weight of first litters were compared. No significant differences occurred (Table 1).

Table 1. Mean \pm s.d. weight at mating, delay of first littering from mating, weight at day of first parturition, and size and pup birth weights of first litters, for the ad-libitum fed (Group AL) and the later food-restricted (Group FR) females

\begin{tabular}{|c|c|c|}
\hline & $\begin{array}{l}\text { Group AL } \\
(N=14)\end{array}$ & $\begin{array}{c}\text { Group FR } \\
(\mathrm{N}=11)\end{array}$ \\
\hline Weight at mating (g) & $23.92 \pm 1.85$ & $23.79 \pm 1.48$ \\
\hline $\begin{array}{l}\text { Delay of first litter } \\
\text { (days) }\end{array}$ & $26.0 \pm 8.1$ & $24 \cdot 1 \pm 7 \cdot 1$ \\
\hline Weight at parturition & $31.79 \pm 1.68$ & $31.09 \pm 1.69$ \\
\hline Litter size & $7.9 \pm 3.5$ & $8 \cdot 5 \pm 1 \cdot 4$ \\
\hline Pup weight (g) & $1.40 \pm 0.17$ & $1.35 \pm 0.07$ \\
\hline
\end{tabular}


Of the 14 females in Group AL, 12 gave birth to a second litter on average at $26 \cdot 0$ days after the first parturition (range 22-30.5 days). However, none of the 11 Group FR females had a second litter (Fisher's Exact Probability test, two-sided: $P<0.0001$ ). Mortality of suckled young did not differ significantly between the two groups: one female pup was found dead and partly eaten by its mother at Day 8 in Group AL, one male was found in a similar condition at Day 9 in Group FR. Within another 2 litters in Group FR, one male pup disappeared at Day 9 and hence must have been cannibalized and one male was found dead but not injured at Day 5 of lactation.

Uteri of Group AL females showed $10 \cdot 79 \pm 3 \cdot 14$ (mean \pm s.d.) implantation sites assigned to the first parturition (see 'Materials and Methods'). Group FR females had only scars from the first parturition (11.45 $\pm 2 \cdot 16$; U-test: NS). The uteri of Group FR females and of the two post-partum infertile dams in Group AL did not show any sign of development of embryo-supporting tissue or capillarization, unlike the uteri of the Group AL females which gave birth to a second litter.

\section{Weight data}

The following comparisons between Groups AL and FR were made excluding the data on the two families in Group AL within which the dams had not given birth to a second litter. Their different reproductive status would add another variate for analysis, and the sample size does not allow for statistical tests.

Weights of post-partum pregnant dams and their pups in Group AL did not differ from those of Group FR females and their young, respectively, at Day 3 of lactation (Table 2). Also, male and female young showed no significant difference in weight at this age (Table 2).

Table 2. Mean \pm s.d. weight of dams and pups at Day 3 of lactation for Group AL families with post-partum pregnant mothers, and Group FR families

\begin{tabular}{lcc}
\hline & $\begin{array}{c}\text { Group AL } \\
(\mathrm{N}=12)\end{array}$ & $\begin{array}{c}\text { Group FR } \\
(\mathrm{N}=11)\end{array}$ \\
\hline $\begin{array}{lcc}\text { Weight of dams (g) } \\
\text { Weight of individual }\end{array}$ & $29.96 \pm 1.47$ & $30.32 \pm 1.57$ \\
$\quad$ pups (g) & $2.19 \pm 0.14$ & $2.13 \pm 0.25$ \\
Weight of males $(\mathrm{g})$ & $2.18 \pm 0.18$ & $2.15 \pm 0.25$ \\
Weight of females $(\mathrm{g})$ & $2.21 \pm 0.11$ & $2.11 \pm 0.26$ \\
\hline
\end{tabular}

The influence of food restriction on weight gains of dams and pups is shown in Fig. 1. The postpartum pregnant dams in Group AL and the Group FR females gained weight at the beginning of lactation and differed in weight gain significantly after Day 14, when Group FR females subsequently lost weight. Mean daily weight loss was maximal at Day 18, i.e. between Days 17 and 18, of lactation in both groups of females (Fig. 1a).

Weight gain of young differed significantly after Day 5 of lactation. Mean daily weight gain of young in both groups was minimal at Day 18 of lactation (Fig. 1b). At Day 22 of lactation the young weighed $10.52 \pm 0.72 \mathrm{~g}$ (mean \pm s.d.) for Group AL and 9.16 $\pm 0.47 \mathrm{~g}$ for Group FR.

Male and female young did not differ in weight gain during lactation at any time in Group AL (Fig. 2). In Group FR, male young gained more weight after the day of minimal growth which became significant at Day 22 (Fig. 2).

\section{Discussion}

One of the intriguing features of the flexible reproductive tactic of house mice is to reduce litter size during lactation by cannibalizing some of the young when food is in short supply (e.g. Smart \& 

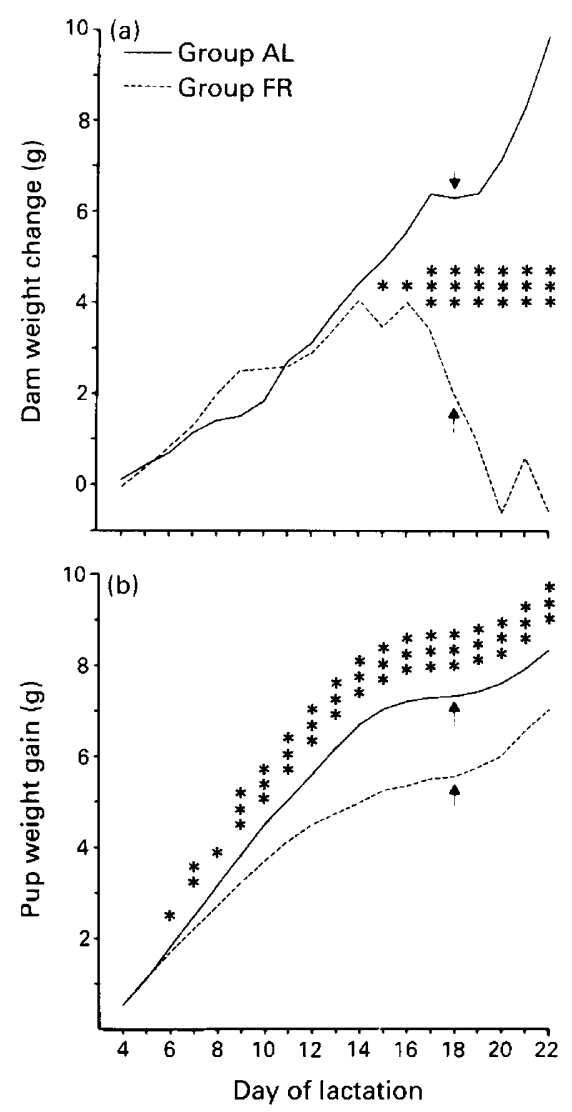

Fig. 1. Mean weight gain of (a) dams and (b) pups with reference to Day 3 of lactation for the ad-libitum fed families with post-partum pregnant mothers (Group AL, $N=12$ ) and the foodrestricted groups (Group FR, $N=11$ ). Arrows indicate the day of minimal prior daily growth. ${ }^{*} P<0.05,{ }^{* *} P<0.01,{ }^{* * *} P<0.001$ (U test).

Silence, 1977; Marsteller \& Lynch, 1983, 1987b; Bronson \& Marsteller, 1985; Perrigo, 1987). This phenomenon has even been observed in wild house mice subjected to food restriction at about $80 \%$ of the amount eaten ad libitum (König, 1985) and has been argued as being to enable a house mouse to produce young of adequate size for survival at the time of weaning (König, 1985; Marsteller \& Lynch, 1987b; Perigo, 1987). Laboratory mouse dams restricted to $80 \%$ of ad-libitum amounts of food consumption do not cannibalize young (Marseller \& Lynch, 1987b). However, these mice gain no weight during lactation as do unrestricted ones.

During the current experiment, food was restricted to $60 \%$ of food consumed by ad-libitum fed BALB/c bom dams under the same conditions (see 'Materials and Methods'). However, it is known that laboratory and wild house mice maintained under such conditions waste a large amount of the consumed food on the cage floor (König, 1985). The Group FR dams gained as much weight as did Group AL females until Day 14 of lactation and did not cannibalize more young than did Group AL dams. Furthermore, at Day 22, the young of Group FR mothers weighed $9 \cdot 16 \mathrm{~g}$ on the average, which is well beyond the $9 \mathrm{~g}$ that König \& Markl (1987) argue is the minimal weaning weight of young at Day 23 of lactation. Consequently, the effective level of food supply used here might have exceeded $80 \%$ and did not compel a mother to diminish her weight gain during lactation or to reduce her lactated litter. 


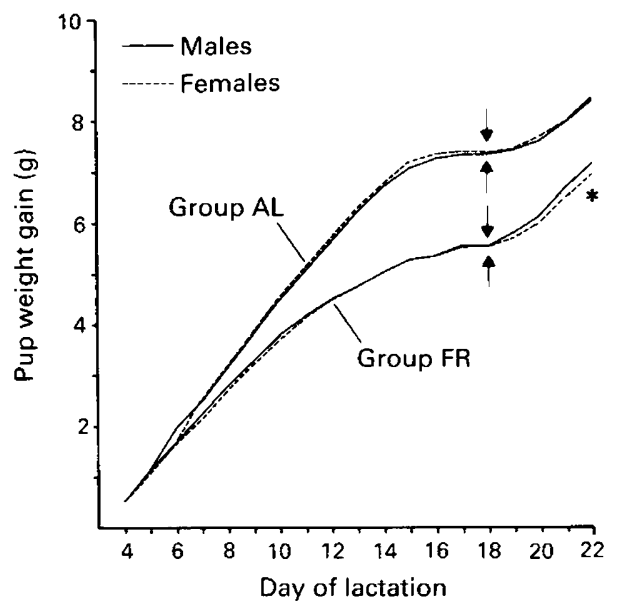

Fig. 2. Mean weight gain of male and female young with reference to Day 3 of lactation for Group AL $(N=14)$ and Group FR $(N=11)$. Arrows indicate the day of minimal prior daily growth. ${ }^{*} P<0.05$ (Wilcoxon test).

In spite of this apparent mildness of food deprivation, none of the Group FR mothers gave birth to a second litter as did 12 of the 14 females in Group AL. In contrast, fertility is not or only slightly reduced in non-lactating house mice by even more severe post-mating food restriction (e.g. McClure, 1961; Smart \& Silence, 1977; Zamiri, 1978; Marsteller \& Lynch, 1987a; Perrigo, 1987).

This infertility might suggest that concurrently pregnant lactating house mice save energetic resources in favour of the lactated litter by pregnancy termination, when food is in shortage. However, it has been shown that the weight gain of the litter to weaning is only very little affected by concurrent pregnancy (Mizuno, 1960; Thompson \& Anderson, 1977; König \& Markl, 1987; Krackow \& Hoeck, 1989). This means that the young in the nest would benefit only slightly from a loss of the young in utero: the mother, on the other hand, would have her next litter about 2 weeks later (e.g. Krackow \& Hoeck, 1989).

The physiological mechanism involved in post-partum fertility failure of Group FR dams is probably the failure of implantation or abortion shortly after implantation. Firstly, since Group FR females were treated exactly as were Group AL females until Day 2 of lactation, i.e. were not food restricted, it seems unreasonable that any effect on ovulation could have been responsible for the infertility of later food-restricted mice.

Secondly, in the Group FR dams uterine scars were found resembling only those of the first litters in Group AL females and there was no tendency for more implantation sites at autopsy. In rats, total litter abortion at 2-5 days after implantation has been observed during food shortage to $25 \%$ of ad-libitum levels (Berg, 1965). Although implanted embryos killed experimentally by colchicine treatment as early as $2-4$ days after implantation in rats may occasionally cause no uterine scars (Conaway, 1955), these resorptions have been identified by counting uterine scars at Day 21 of pregnancy (Berg, 1965). Therefore, pregnancy failure in Group FR dams must involve implantation failure or very early embryonic loss, even though the low energetic requirements of embryos at such an early stage of development should be easily met by the Group FR dams, particularly since house mice are able to save energy by reduction of weight gain during lactation (Marsteller \& Lynch, 1987b).

In conclusion, it appears that implantation after post-partum conception and during lactation is markedly affected by mild nutritional deprivation and is probably due to maternal manipulation and not to immediate consequences of energetic demands of the lactated litter. 
The young from Groups AL and FR gained the least weight between Days 17 and 18 of lactation which is the same day as in litters of non-pregnant BALB/c bom dams (Krackow \& Hoeck, 1989). Also, both groups of females lost the most weight between Days 17 and 18, which is also the first day that lactating mice consume less food than on the previous day in the course of lactation (Myrcha et al., 1969).

Lactating rodent females gain weight at the beginning of lactation, due to enlargement of the alimentary tract, of the liver, and of mammary tissue (Kennedy et al., 1958; Fell et al., 1963; Myrcha, 1964; Hanwell \& Linzell, 1973) and lose weight at the end of lactation again by regression of these tissues. It is therefore suggested that maximal reduction of mammary tissue occurs between Days 17 and 18 of lactation and, concomitantly, energetic requirements of dams drop as does the energetic gain of the young. In Group AL females this weight loss is masked by the weight gain of the litter in utero, but the maximal weight loss is still apparent.

If the above interpretation holds, lactating house mice drop their milk production most markedly at the same day irrespective of whether they are non-pregnant, pregnant or food-restricted. Furthermore, the relative growth of young is virtually identical under each of these conditions (see Krackow \& Hoeck, 1989, for a comparison of litters of pregnant and non-pregnant dams). Hence, the timing of weaning appears to be inflexible in house mice. The dynamics of milk yield are also similar in laboratory mice (König et al., 1988) and laboratory rats (Babický et al., 1973) raising litters of different sizes, in spite of the differences in total milk yield.

The above conclusion is in some disagreement with the conclusions of König \& Markl (1987) who suggest that house mice extend the phase of lactation if pregnant or lactating litters of above average size. However, these authors draw their conclusions mainly from behavioural data and divergence of such data and milk yield (see also Krackow \& Hoeck, 1989) must be considered as a possible source of mismatch in results (Mendl, 1988).

I thank F. Gruber, his animal breeding staff, and two students for help with animal maintenance, breeding and weighing; and $\mathrm{H}$. N. Hoeck and G. Gerlach for comments on the manuscript.

\section{References}

Babický, A., Pařízek, J., Oštádalová, I. \& Kolář, J. (1973) Initial solid food intake and growth of young rats in nests of different sizes. Physiol. Bohemoslov. 22, 557-566.

Berg, B.N. (1965) Dietary restriction and reproduction in the rat. J. Nutr. 87, 344-348.

Bronson, F.H. (1984) The adaptability of the house mouse. Sci. Am. 250, 90-97.

Bronson, F.H. (1985) Mammalian reproduction: an ecological perspective. Biol. Reprod. 32, 1-26.

Bronson, F.H. \& Marsteller, F.A. (1985) Effect of shortterm food deprivation on reproduction in female house mice. Biol. Reprod. 33, 660-667.

Conaway, C.H. (1955) Embryo resorption and placental scar formation in the rat. J. Mammal. 36, 516-532.

Conaway, C.H. (1971) Ecological adaptation and mammalian reproduction. Biol. Reprod. 4, 239-247.

Fell, B.F., Smith, K.A. \& Campbell, R.M. (1963) Hypertrophic and hyperplastic changes in the alimentary canal of the lactating rat. J. Path. Bacteriol. 85, 179-188.

Gilbert, A.N. (1984) Postpartum and lactational estrus: a comparative analysis in rodentia. J. comp. Psychol. 98, 232-245.

Hamilton, G.D. \& Bronson, F.H. (1985) Food restriction and reproductive development in wild house mice. Biol. Reprod. 32, 773-778.

Hanwell, A. \& Linzell, J.L. (1973) The time course of cardiovascular changes in lactation in the rat. $J$. Physiol., Lond. 233, 93-109.

Kennedy, G.C., Pearce, W.M. \& Parrot, D.M.V. (1958) Liver growth in the lactating rat. J. Endocr. 17, $158-165$.

König, B. (1985) Die Brutpflegestrategie die Mäusemutter (Mus musculus): Eltern-Nachkommen Konflikt. Toleranz gegen fremde Junge und Reaktion auf Nahrungsmangel. Ph.D. thesis, University of Konstanz, FRG.

König, B. \& Markl, H. (1987) Maternal care in house mice. I. The weaning strategy as a means for parental manipulation of offspring quality. Behav. Ecol. Sociobiol. 20, 1-9.

König, B., Riester, J. \& Markl, H. (1988) Maternal care in house mice: II. The energy cost of lactation as a function of litter size. J. Zool., Lond. 216, 195-210.

Krackow, S. \& Hoeck, H.N. (1989) Sex ratio manipulation, maternal investment and behaviour during concurrent pregnancy and lactation in house mice. Anim. Behav. (in press).

Marsteller, F. A. \& Lynch, C.B. (1983) Reproductive 
consequences of food restriction at low temperature in lines of mice divergently selected for thermoregulatory nesting. Behav. Gen. 13, 397-410.

Marsteller, F.A. \& Lynch, C.B. (1987a) Reproductive responses to variation in temperature and food supply by house mice. I. Mating and pregnancy. Biol. Reprod. 37, 838-843.

Marsteller, F.A. \& Lynch, C.B. (1987b) Reproductive responses to variation in temperature and food supply by house mice. II. Lactation. Biol. Reprod. 37, 844-850.

McClure, T.J. (1961) Uterine pathology of temporarilyfasted pregnant mice. J. comp. Path. 71, 16-19.

McClure, T.J. (1966) Infertility in mice caused by fasting at about the time of mating. J. Reprod. Fert. 12, 243-248.

Mend, M. (1988) The effect of litter size variation on mother-offspring relationships and behavioural and physical development in several mammalian species (principally rodents). J. Zool., Lond. 215, 15-34.

Mizuno, H. (1960) The effect of concurrent pregnancy on lactation in the mouse. Endocrinol. Japon. 7, 322-326.

Myrcha, A. (1964) Variations in the length and weight of the alimentary tract of Clethrionomys glareolus (Schreber, 1780). Acta theriol. 9, 139-148.
Myrcha, A., Ryszkowski, L. \& Walkowa, W. (1969) Bioenergetics of pregnancy and lactation in White mouse. Acta theriol. 14, 161-166.

Perrigo, G. (1987) Breeding and feeding strategies in deer mice and house mice when females are challenged to work for their food. Anim. Behav. 35, 1298-1316.

Smart, J.L. \& Silence, E. (1977) Problems of undernutrition research with breeding mice. Lab. Anim. 11, 165-168.

Strecker, R.L. (1954) Regulatory mechanisms in housemouse population: the effect of limited food supply on an unconfined population. Ecology 35, $249-253$

Strecker, R.L. \& Emlen, J.T. (1953) Regulatory mechanisms in house-mouse populations: the effect of limited food supply on a confined population. Ecology 34, 375-385.

Thompson, L.J. \& Anderson, R.R. (1977) Effect of pregnancy on lactation in mice. J. Dairy Sci. 60, 126-128.

Zamiri, M.J. (1978) Effects of reduced food intake on reproduction in mice. Aust. J. biol. Sci. 31, 629-639.

Received 27 September 1988 